\title{
ONGS E NEOLIBERALISMO NO BRASIL CONTEMPORÂNEO
}

\author{
COUTINHO, Joana A. \\ ONGs e políticas neoliberais no Brasil. \\ Florianópolis: Ed. UFSC, 2011. 148 p.
}

POR

Jesus Marmanillo Pereira ${ }^{1}$

Q ual a relação entre Organizações Não-governamentais (ONGS) e as Políticas neoliberais no Brasil? 0 que se oculta sob a denominação de não governamental? Como se estruturam essas organizações? Quais suas propostas políticas?

Partindo dessas questões e de um foco de análise sobre a relação Estado-Classes sociais - de seus efeitos no processo de reestruturação do capital - Joana Aparecida Coutinho, cientista social, problematiza o papel dessas organizações no Brasil contemporâneo e expõe o desenvolvimento dessas organizações sob aspectos históricos, discursivos, das relações de trabalho e de suas atuações junto ao Fórum Social Mundial.

Demonstrando a polissemia do termo $\mathrm{ONG}$, inicia o primeiro capítulo demonstrando a flexibilidade ideológica do mesmo. Para problematizá-lo, realiza um breve histórico demonstrando algumas mutações durante a década de 1990. Explica que as "ONGS cresceram na medida em que os movimentos sociais perderam sua força mobilizadora e passaram a adotar uma política integradora através de parcerias com 0 poder público" (p. 20).

Outra discussão travada no capitulo se refere à descentralização da idéia de luta de classe, que paulatinamente perde espaço para outras lutas como: contra a pobreza, pela inclusão social, cidadania etc. Nesse âmbito, estabelece uma relação entre a

\footnotetext{
${ }^{1}$ Doutorando em Sociologia pela Universidade Federal da Paraíba, Brasil. jesusmarmanillo@hotmail.com
} 
percepção fragmentada de reivindicação defendida pela teoria dos novos movimentos sociais e o contexto totalizador do sistema capitalista.

Para aprofundar esse aspecto, discorre sobre as ideologias pós-marxistas associadas às ONGS, a forma como se caracterizam no chamado Terceiro setor e como essas seguem a mesma lógica da atual reestruturação do capital. A autora demonstra que, de forma similar a uma empresa, essas organizações possuem um discurso que legitima as ações, possibilitando financiamentos, e que possuem uma lógica transnacional de divisão do trabalho ideologicamente orientada.

No segundo capítulo, é discutida a relação entre as ONGs e Estado, tomando como ponto de partida uma onda neoconservadora que implicou no estado mínimo na década de 1980 e conferiu às Organizações não Governamentais o status de parceiras situação que adquiriu legitimidade institucional no plano diretor da reforma do aparelho do estado, elaborada por Bresser Pereira.

Considerando o Estado neoliberal enquanto "Estado-empresario", que sempre objetiva menor custo e maior eficiência, e uma perspectiva teórica que substitui a luta de classes pela luta por democratização dos espaços públicos, a autora explica a dificuldade desse estado burguês em encontrar a suposta representação do interesse geral, ocorrendo então os processos de publicização do privado e privatização do público (BOBBIO, 1987).

Nesse âmbito, enfatiza que "as instituições políticas do Estado capitalista ocultam o seu caráter político de classe apresentando-0, ao contrário, como a encarnação da vontade do povo nação." (p. 54) Dessa forma, emergem as condições propicias para o desenvolvimento do terceiro setor, cada vez mais burocratizado (WEBER, 1994) em seus quadros profissionais, mais apto a receber recursos estatais e livres de impostos, por conta de sua denominação (escorregadia) de nãogovernamental e de utilidade pública.

0 terceiro capítulo, as ONGs de responsabilidade social e as Organizações Não Governamentais de Desenvolvimento (ONGDs) são analisadas em relação ao trabalho precarizado, à geração de renda, às ideologias e justificativas que surgem com a crise do capitalismo em sua forma neoliberal.

Considerando o interesse de grandes empresas como a FORD/Rockfeller em preservar a America Latina dos ideais socialistas, a autora explica a relação entre as referidas organizações e as empresas na promoção da responsabilidade social. Percebe que tal relação se desenvolve numa lógica de doação, captação de recursos, geração de lucros e uma serie de isenções de taxas e reduções de impostos.

No campo do trabalho, Coutinho nota que houve uma apropriação do trabalho voluntário, associado ao sentimento de responsabilidade social, ou seja, se antes era uma prática de solidariedade com fins de educação popular e politização, passa a ser 
incorporada como mais uma forma de exploração, ausente de fiscalização e aplicação de direitos trabalhistas conquistados historicamente. Tais aspectos associados ao trabalho são favorecidos pela forma como o estado neoliberal reestrutura o capital por meio de políticas públicas centralizadas, focalizadas e privatizadas, caracterizadas como tipos de programas de socorro a pobreza.

A autora demonstra que há uma lógica de reformismo que prepondera sobre a idéia de ruptura, mesmo nos casos da chamada Economia Solidaria - cujos projetos quase sempre sucumbem ou se tornam empresas capitalistas. Sem ideal de rompimento, tais relações de trabalho fragilizam a capacidade de mobilização e desfocalizam 0 problema existente em uma estrutura de dominação bem mais ampla.

Grosso modo, no último capítulo, é analisada a participação das ONGS no Fórum Social Mundial. São considerados aspectos como, o trabalho fragmentado caracterizado nas varias mesas de discussões, o que dificulta a elaboração de uma proposta global; o perfil dos participantes, que no caso brasileiro não teve a presença dos excluídos, e o tipo de democracia relacionada e reivindicada nesse contexto "uma democracia formal que combina certa igualdade civil coexistente com uma enorme desigualdade social, sem tocar nas relações econômicas entre a elite e a multidão trabalhadora" (p. 127).

Com um rigoroso trabalho de problematização e utilização da teoria marxista, trabalhada em autores como James Petras, Louis Althusser, Ricardo Antunes e outros, Joana Aparecida Coutinho analisa as Organizações Não-Governamentais em relação aos processos de reestruturação do trabalho provenientes do neoliberalismo da década de 1990, e elenca uma serie de questões como: discursos políticos, dinâmicas de financiamento, formas de trabalho utilizado, histórico e outras questões ocultadas sob a denominação $0 \mathrm{NG}$.

Junto a tais questões, nota que a localização entre setores empresariais e o Estado confere a essas organizações uma função de diluição da luta de classes, funcionando assim como um colchão amortecedor das contradições sociais. Nesse sentido, possibilitanos pensar o reformismo das ONGs enquanto um tipo de aparelho ideológico que ofusca os processos revolucionários existentes outrora.

\section{REFERÊNCIAS}

WEBER, Max. Sociologia da dominação: estruturas e funcionamento da dominação. In: Economia e sociedade. Brasília: UnB, 1994. p.187- 356.

B0BBI0, Noberto. A Democracia e o poder invisível. In: O futuro da democracia: uma defesa das regras do jogo. Rio de Janeiro: Paz e Terra, 1987. p. 83107. 